Naamsestraat 61 - bus 3550

B-3000 Leuven - BELGIUM

Tel : 32-16-326661

vives@econ.kuleuven.be

\title{
VIVES 2011
}

\section{DISCUSSION PAPER}

\section{3}

\section{Corporate Taxation,}

\section{Agglomeration and FDI:}

Firm Level Evidence for Belgium

\section{Tim Goesaert}

\author{
tim.goesaert@econ.kuleuven.be
}




\title{
Corporate Taxation, Agglomeration and FDI: Firm Level Evidence for Belgium*
}

\author{
Tim Goesaert ${ }^{\dagger}$
}

Latest update: September, 2011

\begin{abstract}
This paper analyzes the sensitivity of Belgian outbound FDI to corporate taxation rates and economic clustering. Our approach involves detailed balance sheet data of the foreign affiliates as our proxy of FDI and a measure of regional knowledge spillovers as agglomeration variable. The results reveal that investments are sensitive to changes in fiscal policy, with an average tax sensitivity of around -1.5. We also pick up an effect of agglomeration economies: a regional increase in the number of own industry firms dampens tax sensitivity.
\end{abstract}

Keywords: Corporate Tax Competition, Foreign Direct Investment, Agglomeration Economies

JEL Classification Numbers: F21, H25, H87

\section{Introduction and Literature Overview}

It cannot be denied that the level of foreign direct investment worldwide has seen an significant rise over the past decades. Recent World Bank figures reveal that total net FDI inflow has increased to over $2 \%$ of world GDP

${ }^{*}$ I thank the Flemish goverment for the funding of this project through the Steunpunt Fiscaliteit en Begroting. I also thank Joep Konings, Hylke Vandenbussche, Freddy Heylen and Carine Smolders for their support and comments.

${ }^{\dagger}$ VIVES Centre for Regional Economic Policy, LICOS Centre for Institutions and Economic Performance-KU Leuven. E-mail:tim.goesaert@econ.kuleuven.be 
in 2009, compared to roughly $0.6 \%$ in 1980 . With an increasing body of evidence pointing to the potential beneficial effect of FDI for the host countries, regarding e.g. technological innovation, productivity spillovers or employment growth $^{1}$, it should not be surprising that a sizeable part in the economic literature is devoted to explaining the drivers of FDI. The main focus of this paper lies in assessing the sensitivy of foreign investment to fiscal policy.

Concerning tax sensitivity, most studies built their analysis on the basic tax competition model from Zodrow and Mieszkowski (1986), in which a rise in the taxation rate leads to a lower after-tax rate of return and a capital outflow. Recent work also links back to Horstmann and Markusen (1992), which models the decision process of an expanding multinational. First, it deals with the decision to invest or to export. Then, having chosen FDI, the firm needs to decide on the location and the size of the investment. This last step is based on the classical, Jorgensonian investment model: an optimizing firm chooses the amount of investment which equals marginal costs of capital to the marginal benefits. All models seem to predict a negative effect of taxation $^{2}$. Empirical evidence can be traced back to the seminal work of Hartman (1984), which looks at annual FDI inflows into the U.S. using macro data. The focus in this literature, however, remained largely on U.S. studies, concerning aggregate flows, signaling both the economic relevance of these flows and the problem of data availability. An overview of empirical work can be found in the meta study by de Mooij and Ederveen (2003). The authors analyze 25 studies on the tax sensitivity of investments and find a median tax elasticity of investment of -3.3, suggesting the presence of strong tax competition. However, the authors also point to the often heterogeneous results in this literature, which is mainly due to the use of different measures and levels of aggregation.

In this paper we will follow a micro-economic approach within an European context. Our analysis will be based on individual company accounts from the Amadeus database, collected by Bureau van Dijck. This database allows us to link headquarters of Belgian firms with their affliates and to collect balance sheet information on both. The benefit of using firm level data is that it allows us to control for firm characteristics, taking into account information on the headquarter level or sectoral differences. This is often not possible using more aggregate levels of FDI information. Other studies that use individual company data are for instance Buettner and Ruf (2007), which looks at the location decision of affiliates, and Stöwhase (2002), which looks at the impact

\footnotetext{
${ }^{1}$ see e.g., Javorcik, Saggi, and Spatareanu (2004) or Damijan, Knell, Majcen, and Rojec (2003)

${ }^{2}$ More information on the role of taxation can be found in Devereux (2007) or also Gordon and Hines (2002).
} 
of taxes on the number of affiliates, both for German MNEs. In this paper, we will follow the approach from Vandenbussche (2005), Desai, Foley, and Hines (2002) and Desai, Foley, and Hines (2004), in that we define FDI as the change in tangible fixed assets of the affiliates belonging to a multinational group. Often, the literature makes a distinction between the location of the FDI and the amount of FDI invested in that location. We take the location decision as given and look at the amount invested, treating FDI in this paper as a continuous investment decision.

Additional to the sensitivity to tax incentives, we explore the role of agglomeration and geograpic economic clustering on the amount of FDI invested. These agglomeration effects can work through many channels: firms may benefit from an established infrastructure, better logistics, a high-skilled labor force, knowledge spillovers, or other positive external economies ${ }^{3}$. Bobonis and Shatz (2007) found evidence that economic activity in a region, measured by the stock of foreign-owned property, plant and equipment, has a positive impact on the magnitude of inbound U.S. FDI. We will perform a similar test, using a proxy for intra-industry knowledge spillovers. However, we will look for an additional effect: the possible offsetting effect of agglomeration on tax sensitivity, as explored in the New Economic Geography literature. A higher taxation rate in one region will not always induce relocation, given that these agglomeration economies can create quasi-rents for firms and assuming that the productive factors move with their owner (e.g. Baldwin and Forslid, 2002).

In other words, the clustering of economic activity makes the world lumpy. The presence of agglomeration economies allows concentrated or 'core' regions to hold on to mobile factors of production even when their tax rate is set at a higher level than less advanced nations, also called periphery regions. By dividing nations or regions into 'core' or rich nations versus 'periphery' or poor regions Baldwin and Krugman (2004) point out that differences in tax rates can be sustainable and even persistent, without generating tax competition. They show in fact that greater economic integration, related to intermediate trade costs, may lead to a 'race to the top' rather than a 'race to the bottom'. The key mechanism is that the 'core' region creates an agglomeration rent through the concentration of economic activity with important linkages in supply chains and strong demand. Agglomeration thus means that industry is not indifferent to where it locates as it can earn more in the core than in the periphery. Hence, governments can tax their industry

\footnotetext{
${ }^{3}$ These are determined endogenously through the interaction of agglomeration forces with dispersion forces: when regions get congested, land prices, office prices and wages tend to rise as well. Furthermore, local competition is intensified, which may trigger firms to move to less dense regions to avoid competition and enjoy local monopoly power.
} 
in the core at a higher rate than in the periphery. Of course there are limits to the tax difference that can be supported in the presence of such external effects or agglomeration economies. If the agglomeration benefits are entirely taxed away, dispersion forces may start dominating which may be irreversible. For a detailed analysis of the mechanisms behind agglomeration forces and dispersion forces see also Combes, Mayer, and Thisse (2008).

Besides the perceived benefits of attracting inward FDI flows, this line of research has other important consequenses for policy makers as it delivers more insights on the magnitude of tax competition. Looking at the current situation in the European Union, the low taxation rates of the new member countries have fueled the debate on harmful tax competition. Traditional theory suggests that with perfect mobility of capital a suboptimal capital tax rate will emerge, as governments try to attract more capital. This may well lead to a race to the bottom of taxation rates ${ }^{4}$. Recently, a more nuanced view on tax competition has emerged with the introduction of the New Economic Geograpy models. However, with further economic integration and capital becoming more mobile, it should be no surprise that tax harmonization has been getting increased attention in EU debates.

The structure of this paper is as follows: the next section discusses the data and methodology in further detail. We will present our results in section 3 and discuss additional robustness checks in the 4th section. We conclude this paper in section 5 .

\section{Data and Methodology}

\subsection{Data Sources}

Our empirical work is primarily based on the Amadeus database, collected by Bureau van Dijck. It provides access to balance sheet data and company accounts of European incorporated firms. While inclusion criteria can differ

\footnotetext{
${ }^{4} \mathrm{~A}$ small but growing literature has started to explore empirically the fiscal interactions between governments by estimating a tax reaction function over corporate tax rates, using spatial econometric methods. The difference between these papers lies in the composition and modeling of the reaction functions. Crabbé and Vandenbussche (2008) work within the enlarged EU and weigh the other countries' taxes by distance, finding that the further a country is from a low tax region, the higher the tax premium it can set. Davies and Voget (2008) operate in a similar setup, but they comprise more countries and use market potential as a weighing tool. They find that EU members seem to react more to tax changes of other EU countries, which hints to the possibility of tax competition within the European Union. Exbrayat (2008) looks at OECD corporate tax rates and finds evidence of an agglomeration rent in the tax setting behavior of countries.
} 
between countries due to differences in national accounting legislation, the database has a good coverage, especially for medium and large scale firms ${ }^{5}$. Apart from financial and operational information, the data cover also other firm characteristics, such as the ownership structure (including details on direct and indirect shareholders). This allows us to recreate the group structure of multinational enterprises, connecting headquarters to their affiliates. By making this link, we thus obtain a dataset of European affiliates linked to their parent company. We restrict our analysis to multinationals that have Belgian headquarters (parents), defined as being the global ultimate owner of their group with a controlling stake of at least $50 \%$ in their affiliates. The distribution of our final sample is depicted in table 1. We obtained $26 \mathrm{EU}$ host countries in the period 1997-2005 and we identified 972 daughter companies of Belgian MNE. Roughly 70\% of affiliates are located in Belgium's neighboring countries. Spain and Italy are also well represented in our sample. Further summary statistics are shown in table 2 . We note that the distribution is highly skewed and that affiliate companies have on average fewer assets, sales and employees. About one third of all firms in the sample are in the manufacturing sector.

\subsection{Taxation Rates}

We first turn to the measurement of the taxation variable. Various approaches have been adopted in the literature (see e.g. Devereux, 2007). We start with the statutory corporate taxation rate (STR). This is easily available and straightforward to use. It can also act as a signaling device, which facilitates firms' investment decisions. There are some downfalls to this measure. By only focusing on the taxation rate, it ignores the impact of the taxation base when assessing the taxation burden firms face. It is in fact possible that low statutory tax rates might be compensated by a broadening of the taxation base (e.g. Devereux and Griffith, 2003; Crabbé and Vandenbussche, 2008), making the final outcome for firms not that favorable as originally expected. Another complication can be that, by just using the average or top STR rate, the progressivity of the tax system (which is applied in a number of countries) is often ignored. We also consider effective tax rates, which take the tax base into account. Concerning their computation, both ex post as ex ante measures are available (Nicodème, 2001). The former are defined by the ratio of tax payments and total pre-tax profits of firm. This computation can be

\footnotetext{
${ }^{5}$ In recent years many researchers have used this data base for a variety of applications. See for instance Budd et al. (2005) for an application of international rent sharing in European Multinational Enterprises or Helpman et al (2003) for the export decision of firms
} 
Table 1: Distribution of Affiliates

\begin{tabular}{lclc}
\hline Country & Affiliates & Country & Affiliates \\
\hline Austria & 5 & Lithuania & 1 \\
Bulgaria & 1 & Luxembourg & 6 \\
Croatia & 4 & Norway & 8 \\
Czech Republic & 28 & Poland & 37 \\
Denmark & 20 & Portugal & 2 \\
Estonia & 2 & Romania & 14 \\
Finland & 10 & Russia & 2 \\
France & 427 & Slovakia & 6 \\
Germany & 14 & Spain & 78 \\
Greece & 9 & Sweden & 31 \\
Ireland & 6 & The Netherlands & 83 \\
Italy & 53 & Ukraine & 2 \\
Latvia & 2 & United Kingdom & 121 \\
\hline
\end{tabular}

Source: Amadeus and own calculations.

Table 2: Summary Statistics

\begin{tabular}{lcc}
\hline Variable & Affiliates & Headquarters \\
\hline Total assets (x 1,000 euro) & $90,103.5$ & $102,234.3$ \\
& $(380,253)$ & $(500,368)$ \\
Number of employees & 150.303 & 253.979 \\
& $(239.819)$ & $(950.742)$ \\
Total sales (x 1,000 euro) & $74,004.84$ & $92,123.45$ \\
& $(93,706.22)$ & $(313,213.4)$ \\
Percentage of firms in manufacturing & $30.32 \%$ & $25.24 \%$ \\
\hline
\end{tabular}

Source: Amadeus and own calculations. Standard errors are in parentheses. 
performed using both macro- and micro-level information, such as national accounts or income sheet data. By construction, this measure captures the history of both firm and country tax systems. Ex ante measures, on the other hand, are calculated for a hypothetical and well defined investment project, which makes its computation often cumbersome. Moreover, as the type and financing of the investment are defined very specifically, the measure can be less appropriate for some of the investments we analyze. However, the ex ante measures are preferred as they succeed more in capturing the tax incentives firms face. When comparing this to backward looking tax indicators, the influence of past history may cause two identical firms to incur different tax liabilities, making it difficult to evaluate the effect of tax legislation (Elschner and Vanborren, 2009). Also, the ex ante indicators do not suffer from endogeneity bias, unlike the ex post measures ${ }^{6}$. Two types of ex ante rates exist: the effective average tax rate (EATR) is often used when looking at discrete location decisions, the effective marginal tax rate (EMTR) when assessing investments at the margin (Devereux and Griffith, 2003). As we are studying the impact of taxation on existing firms, where the location decision has already been made, an EMTR is more suited. However, as studies on tax sensitivity and FDI often use all three tax burden measures, we will include both measures in the robustness checks.

The effective rates that we will use in this study are calculated in Devereux, Griffith, and Klemm (2002). They provide EMTRs and EATRs of a number of European countries, which are updated regularly by the Institute for Fiscal Studies $^{7}$. These rates are derived for hypothetical investments in plant and equipment and industrial buildings, financed by either equity or debt. This measure will capture the effect of the statutory tax rate, as well as depreciation allowances and other tax concessions. These rates, however, do not fully cover our full set of host countries, which implies that we cannot include a number of, mainly Eastern European, host countries ${ }^{8}$. An overview of all available taxation measures is given in figure 1, where we display the average EMTR, EATR and STR for the period 1995-2005. The effective rates remain on average below the statutory rate, indicating that tax concessions and allowances are of a certain importance in assessing the tax burden. However, the magnitude of the difference between the two rates can differ among countries. Ireland, which had on average a low statutory tax rate during the

\footnotetext{
${ }^{6}$ As periods of high investment can lead to higher allowances, the ex post taxation measure will give a lower estimate of the tax burden. This will establish the expected sign, but suffers from reversed causality (Devereux, 2007).

${ }^{7}$ For more information, see http://www.ifs.org.uk.

${ }^{8}$ We have no information on Bulgaria, Croatia, the Czech Republic, Denmark, Estonia, Latvia, Lithuania, Luxembourg, Poland, Romania, Russia, Slovakia and Ukraine
} 
observation period, has a very similar EMTR. Italy, on the other hand, has a much larger gap between STR and EMTR.

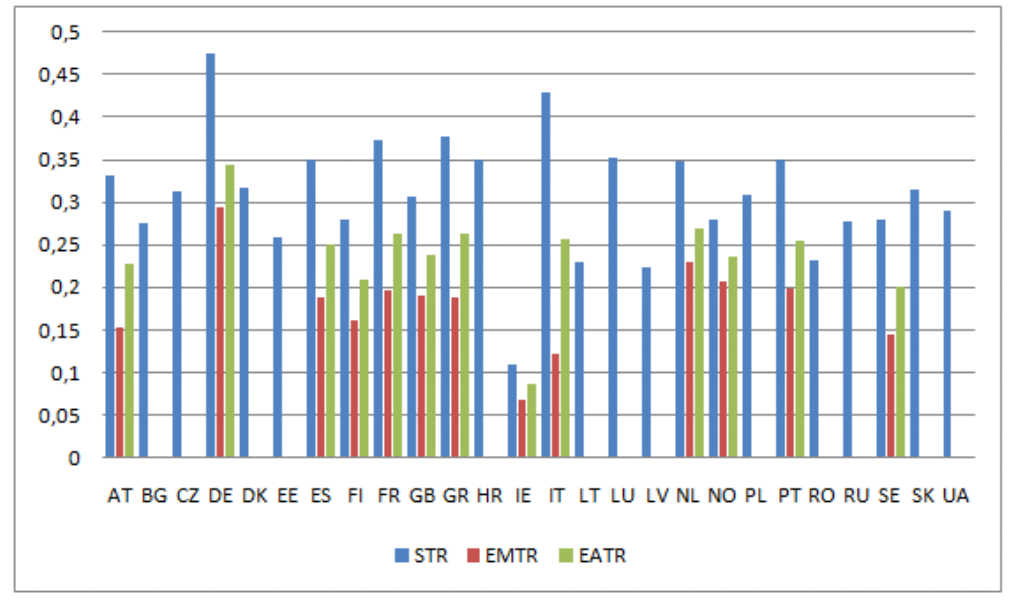

Figure 1: Average EMTR, EATR and STR (1995-2005)

Finally, it is important to consider some implications of international taxation. Multinational firms face a problem of double taxation, meaning that the profits in their affiliates can get taxed twice: once in the home country of the MNE and once in the country that hosts the affiliate company. Tax treaties have been set up to resolve this situation, resulting in two main approaches. In the credit system, used by e.g. US, Ireland, UK or Italy, the headquarter firm is subject to the host country's tax regime, but can subtract these expenses from its tax payments it faces in the home country. In the exemption system, used by most EU countries, the profits are only taxed in the home country of the parent firm (de Mooij and Ederveen, 2003). Thus, the profits of the affiliates are taxed in the host country only. These two measures might lead to different incentives: a firm located in a country using the credit system might be less sensitive towards the taxation rate in the host country as it can benefit from some tax deduction in the home country. By contrast, firms active in an exemption system can not reclaim their foreign tax payments and might face a more hostile environment abroad, resulting in fewer investments. Empirical justification for this theory is still missing. Since our dataset contains information on Belgian headquarters only and their affiliates, the exemption system is the relevant one to consider. 


\subsection{Agglomeration effects}

Whereas the effect of economic clustering is widely studied, the measure itself can take many forms. Broadly defined, one can think of rich versus poor regions, based on GDP per capita, or densily versus thinly populated areas, using population figures. We will construct a more detailed variable, based on intra-industry knowledge spillovers. This view dates back from Marshall (1890), who stated that knowledge spillovers originate from interaction between workers of the same industry. We construct this measure using firm level data from Amadeus BvD, summing the number of same industry firms at the 2-digit NACE and 3-digit NUTS level ${ }^{9}$. For sector $i$, region $r$ and time $t$, this becomes:

$$
K S_{i r t}^{f}=\log \left[N_{i r t}\right]
$$

We will include a similar measure of knowledge spillovers in the robustness section, summing the total number of employees at the 2-digit NACE level for each region, defined at the 3-digit NUTS level. However, due to incomplete reporting of employment levels in Amadeus BvD, this measure might suffer more from measurement error. We subtract own employment from the total sum to avoid endogeneity issues. In order to calculate the logarithm, we add 1 . Without this, our measure would be zero for industries with only 1 representative. For firm $j$ in sector $i$ and region $r$ at time $t$, we get:

$$
K S_{\text {jirt }}^{e}=\log \left[\sum_{j \in i \cap r} E_{j i r t}-E_{\text {jirt }}+1\right]
$$

Concerning the offsetting effect of economic clustering on tax sensitivity, one has to bear in mind that the NEG-framework departs from the classical tax competition models and that it focuses mainly on the location decisions of profitable firms. Note that we considered our investments to be continuous, conditional on the location choice, which makes our outcome a priori unclear. As some changes in the assets we observe might originate from discrete, profitable projects for which affiliates of a firm are competing, we could still pick up this effect. Moreover, there have been attempts to model externalities from clustering in the traditional tax competition literature. Krogstrup (2008) shows that, when introducing external economies of scale, a race to the top is possible within a classical model ${ }^{10}$.

\footnotetext{
${ }^{9}$ We use the date of incorporation, available in Amadeus, to construct this measure based on startups.

${ }^{10}$ Introducing increasing marginal productivity of capital, she assumes that the effect of external economies outweighs the firm level decreasing marginal productivity of capital.
} 


\subsection{Model and Specifications}

For our baseline equation we follow Desai, Foley, and Hines (2002) and Desai, Foley, and Hines (2004). In particular, we want to study the impact of corporate taxes in the host country on the total amount of tangible fixed assets invested in the affiliates by a multinational group. An investment abroad by a MNE is generally considered as a foreign direct investment if that company owns a minimum stake of $10 \%$ in the receiving company (European Union Direct Investment Yearbook, 1997). However, in order to get a better identification of Belgian outbound FDI, we will retain the firms which have a direct or total ownership share equal to or larger than $50,01 \%$. We consider all three measures of the tax burden, as discussed above: the statutory taxation rate, the effective average tax rate and the effective marginal tax rate.

In addition, we add a proxy for the geographic clustering of economic acitivity in each region. First, we will test whether regions with more intra-industry knowledge spillovers can attract more FDI. Then, we add an interaction term between our agglomeration and taxation measures. This is to see if we can pick up an offsetting effect of agglomeration on the tax sensitivity. A positive sign on the interaction coefficient indicates that the higher the externalities from economic clustering, the lower the tax sensitivity of outbound investments in the affiliates. We summarize these effects in estimating the following equation:

$$
\log T A_{j i r t}^{m n}=\alpha_{j}+\beta_{1} T A X_{t}^{n}+\beta_{2} K S_{i r t}+\beta_{3} K S_{i r t} T A X_{t}^{j}+\beta_{4} X_{j i r t}^{m n}+\epsilon_{j i r t}^{m n}
$$

Our dependent variable in this equation is the natural logarithm of tangible fixed assets of affiliate $j$ in host country $n$ at time $t$, belonging to multinational group $m$. Fixed effects are defined on the firm level, using $\alpha_{j} . T A X_{t}^{n}$ is our taxation measure defined for country $n$ and time $t$; KS our measure for economic clustering as defined above. $X_{j i r t}^{m n}$ controls for variables on the country, regional, group or firm level. As is common to this literature, we include three powers of GDP of the host country, reflecting the fact that larger countries are able to attract more capital. Given that the measure for the tax burden is either a statutory tax rate, or an effective one, calculated for a hypothetical investment project, we consider it to be unaffected by the investment decision of individual firms. If large scale firms are indeed capable to influence local tax policy, their bargaining position is controlled for through the fixed effects, assuming that this does not change over our observation period. 


\section{Baseline Results}

In a first line of regressions, we test whether we find an effect of taxation and agglomeration on the amount of investments, using the statutory taxation rate and the industry specific knowledge spillover measure, constructed by summing the amount of own industry firms.. We define investment as the change in tangible fixed assets. To correct for the possible correlation of error terms within a multinational enterprise, we cluster the standard errors on the MNE group level. All specifications contain firm fixed effects, year dummies and GDP controls. In addition, we will also control for group dynamics by including the logarithm of headquarters' total assets. In doing so, we try to control for shocks affecting the investment decision at the group level. We restrict our sample to all non Belgian affiliates in our sample with a minimum 50.01 percent stake of the controlling headquarter. The results are presented in Table $3^{11}$.

In the first two columns we only consider the tax variable. We include the agglomeration variable in columns (3) and (4), then add the interaction term in columns (5) and (6). The first four columns reveal a negative tax sensitivity of about -1.5 , which is still in line with the semi-elasticity of -3.2 , as reported in the meta-study of de Mooij and Ederveen (2003) ${ }^{12}$. These results hold after controlling for group specific shocks. We do not pick up a significant effect of the intra-industry knowledge spillovers in columns (3) and (4). Turning to the last two specifciation, we again observe a negative coefficent for the tax variable. However, in order to asses the full tax sensitivity, one has to take the interaction term into account. This coefficient is positive and significant, which could provide evidence of the possible dampening effect of agglomeration on the tax sensitivity of firms: as the number of own industry firms grows, they become less sensitive to changes in taxation.

\section{Robustness Checks}

In this section we will perform some additional robustness checks. Table 4 and 5 consider the alternative measures for our tax burden: the effective average tax rate and the effective marginal tax rate. We note that these variables still capture a negative effect of taxation, but their significance drops slightly.

\footnotetext{
${ }^{11}$ We performed an additional robustness check, considering only firms under full ownership. This yielded similar results.

${ }^{12}$ These coefficients have to be interpreted as a semi-tax rate elasticity, meaning that it measures the percentage change in assets resulting from a percentage point change in the taxation rate.
} 


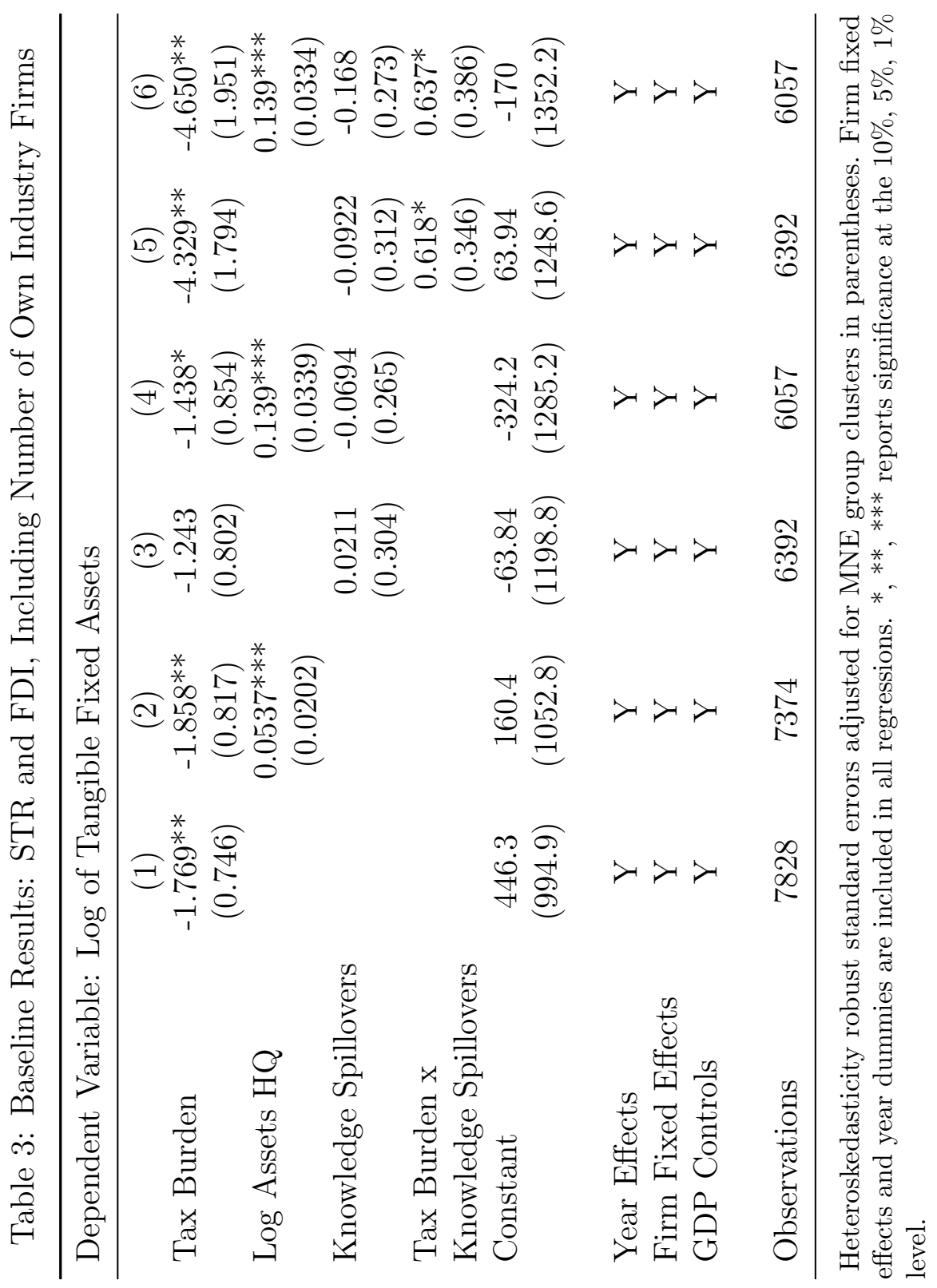




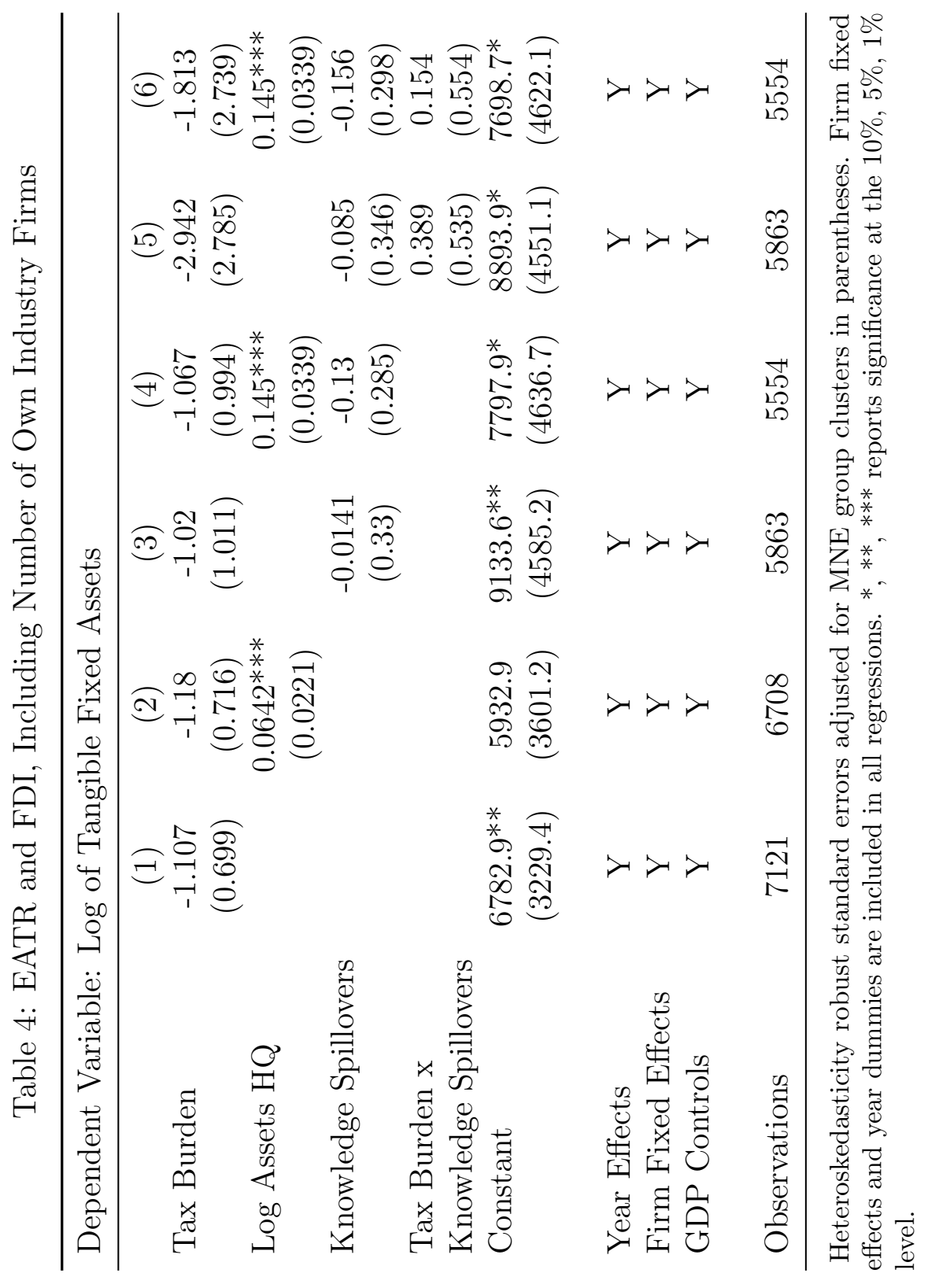




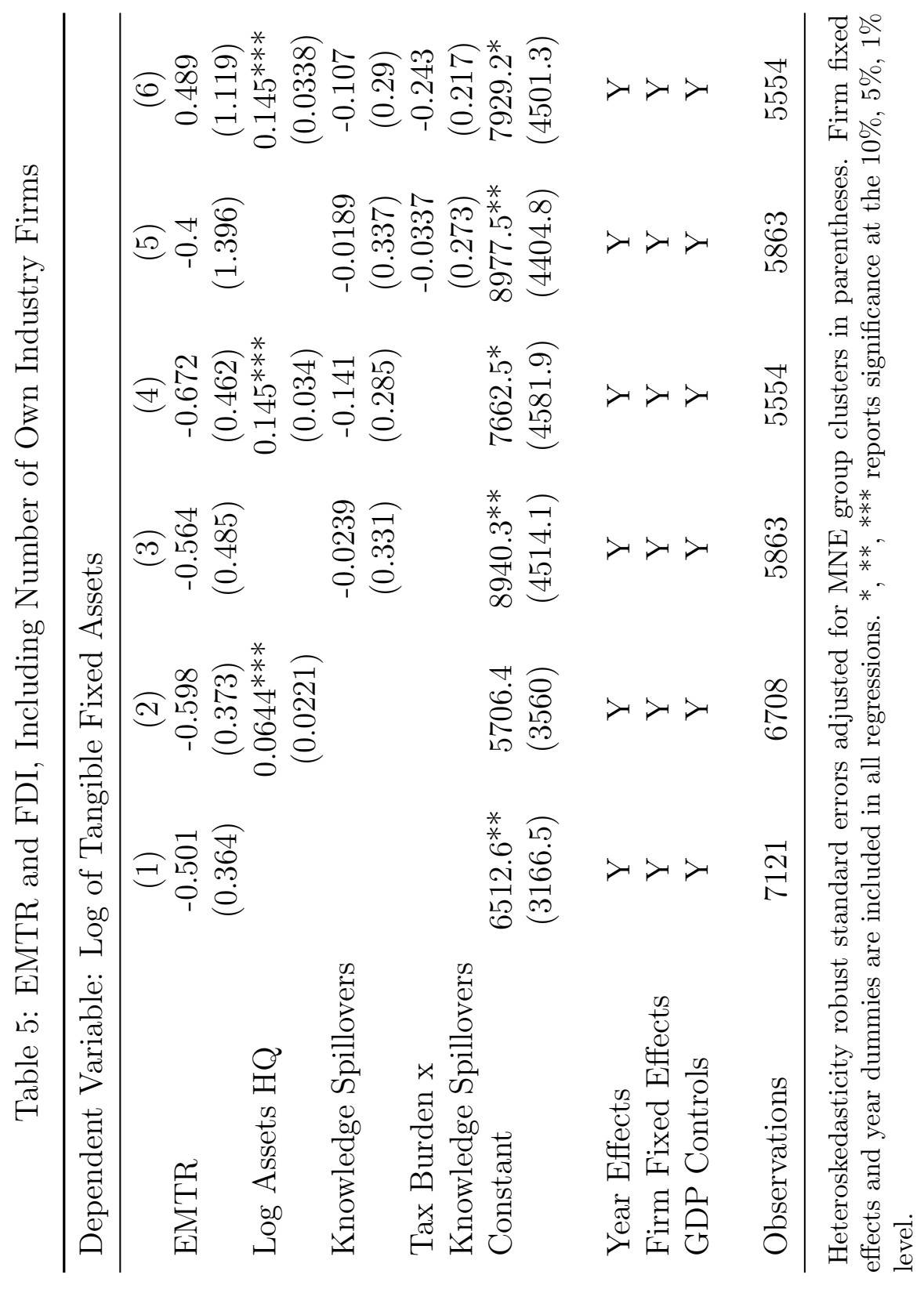


Turning to the spillovers, these measures fail to pick up a dampening effect on tax sensitivy: the coefficient of the interaction term is not significant in any of the two tables. A possible explanation for this drop in significance might be related to the various assumptions used for the construction of a hypothetical tax burden.

Table 6: STR and FDI, Including Own Industry Employment

\begin{tabular}{lcccc}
\hline Dependent Variable: Log of Tangible Fixed Assets & \\
\hline & $(1)$ & $(2)$ & $(3)$ & $(4)$ \\
Tax Burden & -1.584 & -1.5 & -4.362 & -4.468 \\
& $(1.146)$ & $(1.243)$ & $(3.476)$ & $(3.606)$ \\
Log Assets HQ & & 0.0085 & & 0.00743 \\
& & $(0.0214)$ & & $(0.0211)$ \\
Knowledge Spillovers & $0.157^{* *}$ & $0.133^{*}$ & 0.0406 & 0.00875 \\
& $(0.0731)$ & $(0.0753)$ & $(0.14)$ & $(0.146)$ \\
Tax Burden x & & & 0.331 & 0.355 \\
Knowledge Spillovers & & & $(0.394)$ & $(0.407)$ \\
Constant & 53.6 & -117.5 & 69.79 & -114.1 \\
& $(1300.3)$ & $(1321.6)$ & $(1309.1)$ & $(1325.5)$ \\
& & & & \\
Year Effects & $\mathrm{Y}$ & $\mathrm{Y}$ & $\mathrm{Y}$ & $\mathrm{Y}$ \\
Firm Fixed Effects & $\mathrm{Y}$ & $\mathrm{Y}$ & $\mathrm{Y}$ & $\mathrm{Y}$ \\
GDP Controls & $\mathrm{Y}$ & $\mathrm{Y}$ & $\mathrm{Y}$ & $\mathrm{Y}$ \\
& & & & \\
Observations & 4467 & 4207 & 4467 & 4207 \\
\hline
\end{tabular}

Heteroskedasticity robust standard errors adjusted for MNE group clusters in parentheses. Firm fixed effects and year dummies are included in all regressions. $*, * *, * * *$ reports significance at the $10 \%, 5 \%, 1 \%$ level.

Finally, we reconsider the role of agglomeration on FDI in table 6, looking at statutory rates only. We introduce an alternative proxy for economic clustering: we reconstruct our knowledge spillovers based on the amount of own industry employment. The interaction term is included in columns (3) and (4). We reconfirm the negative coefficient of our taxation variable in all specifications, but this is only mildly signifciant ${ }^{13}$. Regarding the spillover effects in columns (1) and (2), we note a positive and significant effect: an increase in own sectoral employment is linked to an increase of investments in the affiliate. In the last two columns we turn to the possible dampening effect

\footnotetext{
${ }^{13} \mathrm{P}$-values range between 0.16 and 0.23 .
} 
of agglomeration on tax sensitivity. We do not seem to pick up an effect in this setup: although all coefficents have the expected signs, they no longer are significant. However, it could well be that this agglomeration variable, based on employment figures, might be less accurate due to incomplete reporting in the Amadeus database.

\section{Conclusion}

This paper analyzed the impact of corporate taxes on the investment decisions of multinational firms. To this end, we constructed a panel dataset of multinational enterprises with headquarters in Belgium and matched them to their affiliates located in other European countries. We find an investment elasticity with respect to the statutory tax rate of around -1.5 on average, which is in line with earlier results in the literature. The elasticity and significance drops slightly for our effective taxation measures.

Regarding agglomeration economies, we have tested the effect of intraindustry knowledge spillovers using a detailed industry specific measure at the 3-digit NUTS level. We find some evidence of a dampening effect of agglomeration on tax sensitivity: an increase in the number of own industry firms makes firms less sensitive to changes in the statutory tax rate. 


\section{References}

Baldwin, R., and R. Forslid (2002): "Tax Competition and the Nature of Capital," CEPR Discussion Papers 3607, C.E.P.R. Discussion Papers.

Baldwin, R. E., And P. KRugman (2004): "Agglomeration, integration and tax harmonisation," European Economic Review, 48(1), 1-23.

Bobonis, G., And H. Shatz (2007): "Agglomeration, adjustment, and state policies in the location of foreign direct investment in the United States," The Review of Economics and Statistics, 89(1), 30-43.

Buettner, T., And M. Ruf (2007): "Tax incentives and the location of FDI: Evidence from a panel of German multinationals," International Tax and Public Finance, 14(2), 151-164.

Combes, P., T. Mayer, and J. Thisse (2008): Economic geography: The integration of regions and nations. Princeton Univ Pr.

Crabbé, K., and H. Vandenbussche (2008): "Are your firm's taxes set in Warsaw? Spatial tax competition in Europe," LICOS Discussion Papers 21608, LICOS - Centre for Institutions and Economic Performance, K.U.Leuven.

Damijan, J., M. Knell, B. Majcen, and M. Rojec (2003): Technology transfer through FDI in top-10 transition countries: how important are direct effects, horizontal and vertical spillovers? Institute for Economic Research.

Davies, R. B., And J. Voget (2008): "Tax Competition in an Expanding European Union," Working Papers 0830, Oxford University Centre for Business Taxation.

De Mooij, R. A., And S. Ederveen (2003): "Taxation and Foreign Direct Investment: A Synthesis of Empirical Research," International Tax and Public Finance, 10(6), 673-93.

Desai, M. A., C. F. Foley, and J. J. Hines (2004): "Foreign direct investment in a world of multiple taxes," Journal of Public Economics, 88(12), 2727-2744.

Desai, M. A., C. F. Foley, and J. R. Hines (2002): "Chains of Ownership, Regional Tax Competition, and Foreign Direct Investment," NBER Working Papers 9224, National Bureau of Economic Research, Inc. 
Devereux, M. P. (2007): "The Impact of Taxation on the Location of Capital, Firms and Profit: a Survey of Empirical Evidence," Working Papers 0702, Oxford University Centre for Business Taxation.

Devereux, M. P., And R. Griffith (2003): "The Impact of Corporate Taxation on the Location of Capital: A Review," Economic Analysis and Policy (EAP), 33(2), 275-292.

Devereux, M. P., R. Griffith, and A. Klemm (2002): "Corporate income tax reforms and international tax competition," Economic Policy, 17(35), 449-495.

Elschner, C., and W. Vanborren (2009): "Corporate Effective Tax Rates in an Enlarged European Union," Taxation Papers 14, Directorate General Taxation and Customs Union, European Commission.

ExBrayat, N. (2008): "The Impact of Trade Integration and Agglomeration Economies on Tax Interactions : Evidence from OECD Countries," Working Paper.

Gordon, R. H., And J. J. Hines (2002): "International taxation," in Handbook of Public Economics, ed. by A. J. Auerbach, and M. Feldstein, vol. 4 of Handbook of Public Economics, chap. 28, pp. 1935-1995. Elsevier.

Hartman, D. G. (1984): "Tax Policy and Foreign Direct Investment in the United States," National Tax Journal, 37(4), 475-488.

Horstmann, I. J., And J. R. MARkusen (1992): "Endogenous market structures in international trade (natura facit saltum)," Journal of International Economics, 32(1-2), 109-129.

Javorcik, B. S., K. Saggi, and M. Spatareanu (2004): "Does it matter where you come from? vertical spillovers from foreign direct investment and the nationality of investors," Policy Research Working Paper Series 3449, The World Bank.

Krogstrup, S. (2008): "Standard tax competition and increasing returns," Journal of Public Economic Theory, 10(4), 547-561.

Marshall, A. (1890): "Principles of economics," 8th ed. Macmillan, London.

NiCODÈme, G. (2001): "Computing effective corporate tax rates: comparisons and results," European Economy - Economic Papers 153, Directorate General Economic and Monetary Affairs, European Commission. 
Stöwhase, S. (2002): "Profit Shifting opportunities, Multinationals, and the determinants of FDI," Discussion Papers in Economics 29, University of Munich, Department of Economics.

Vandenbussche, H. (2005): "Vennootschapsbelasting in Europees Perspectief," Policy report, VKW Metena.

Zodrow, G., And P. Mieszkowski (1986): "Pigou, Tiebout, property taxation, and the underprovision of local public goods," Journal of Urban Economics, 19(3), 356-370. 